\title{
ナミアゲハの産卵刺激物質を認識する味覚受容体 チョウと植物を結ぶ䋖を化学感覚の仕組みから解明する
}

現在，学名がつけられている全生物種（動物のみでは なく，植物・菌類・原生生物など，すべての生物を含 む）は約 200 万種とされているが，昆虫がその過半数を 超えている，多種多様な昆虫の生活史もさまざまで，本 能行動の規則的な連鎖で構築される複雑な生命現象は, ダーウィン進化論を否定するつもりはなくとも，本当に 偶然の積み重ねだけで成り立つものなのかと疑問を抱い てしまうほど巧妙である．昆虫は化合物を認識すること で外界の情報を得て, 寄主選択・配偶行動・集団生活の 維持・社会性の構築など, 生存上重要となるさまざまな 場面で利用しているので，化合物を認識する仕組みを解 明することができれば，生命現象をより梁く理解するこ とができるはずである.

地球上で最も多様化している昆虫のなかで, 植食性昆 虫がその過半数を占める. 鱗翅目昆虫（チョウとガ）は 2番目に多くの種が記載されているグループであるが, 大部分が植食性で，その多くは幼虫が特定の植物のみを 食べるという性質がある.

アゲハチョウの仲間も, 幼虫が狭い範囲の植物のみを 食べることが知られている。私たちが研究材料として用 いているナミアゲハ (Papilio xuthus:一般的に単に 「アゲ八」と呼ばれることも多いが, アゲハチョウ科全 体の話題なのか紛らわしいこともあるので，ここでは明 確にするためにナミアゲ八と呼ぶ）も，幼虫がミカン科 の植物のみを食べる。しかし，卵から孵ったばかりの初 齢幼虫は, 体長が約 $1.5 \mathrm{~mm}$ と小さく, 移動能力が低い ので, 広い環境中から自力で慨を見つけ出すのは難し い.そこで, 飛ぶことができて移動能力が高いメス成虫 が，植物種を正確に見分けて幼虫が食べられるものを選 んで産卵する，成虫は花の蜜を飲んでいるので植物を食 べることはないが，産卵行動を引き起こすキーになって いるのが「味覚」である.

体外の化合物を認識するという意味においては味覚も 嗅覚も同様の機能であるが, 陸棲生物に関しては, 水溶 性や脂溶性の不揮発性の化合物を感覚組織が接触して認 識するものを「味覚」, 空気中を漂う揮発性の化合物を 非接触的に認識しその情報が糸球体（嗅受容細胞と，情 報を受発信する出力神経や局所介在神経が球状に絡み
合った神経繊維の集合体）へ投射される場合を「嗅覚」 と定義される．アゲハチョウの仲間の前脚先端部にある ふ節と呼ばれる組織には味覚感覚子があり（図 1A），前 脚で植物を吒くドラミング行動によって「味見」をし て，幼虫が食べられる植物を見分けているのである．ナ ミアゲ八については，主な食草であるミカン科植物か ら，葉に含まれている化合物 10 種が「産卵刺激物質」 として同定されており（図2），これらを混合すると生

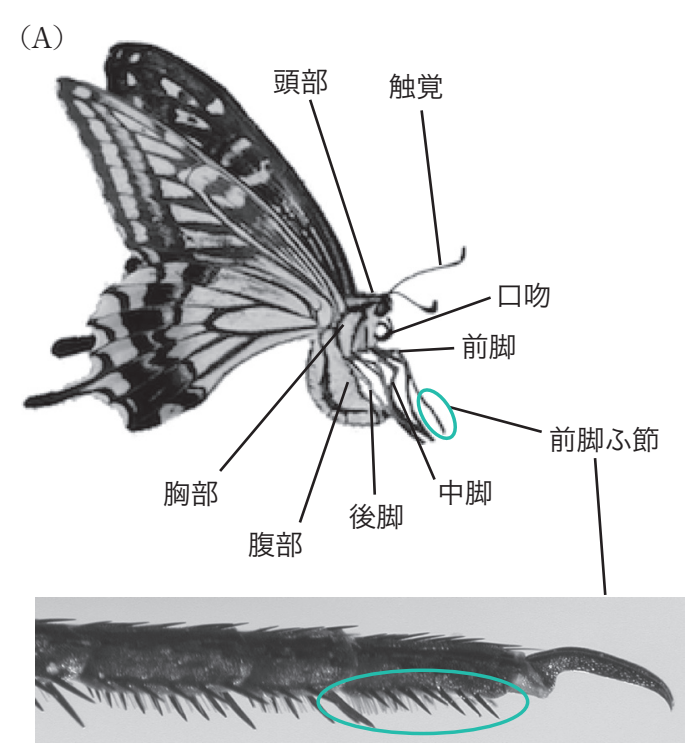

(B)

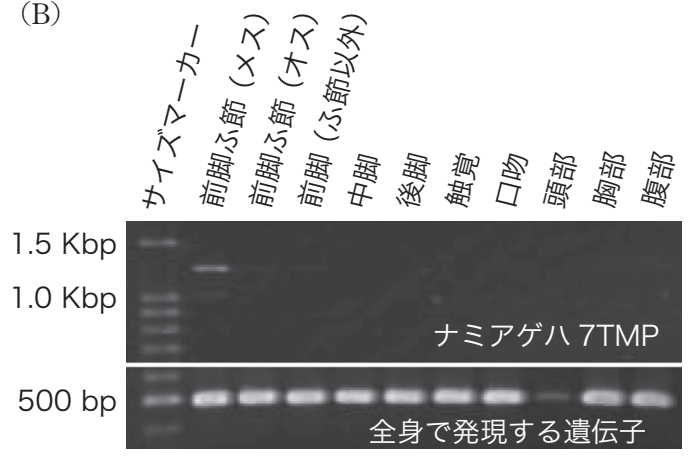

図 1ロナミアゲ八の組織と味覚受容体遺伝子（7TMP）の発現 部位

A : チョウの組織と前脚ふ節感覚子. 緑丸は第 5 ふ節の感覚子が目 立つ部分. B : 味覚受容体が発現している組織. RT-PCRによる電 気泳動の結果, メスの前脚ふ節でのみ発現が見られた。 


\section{今日の話題}

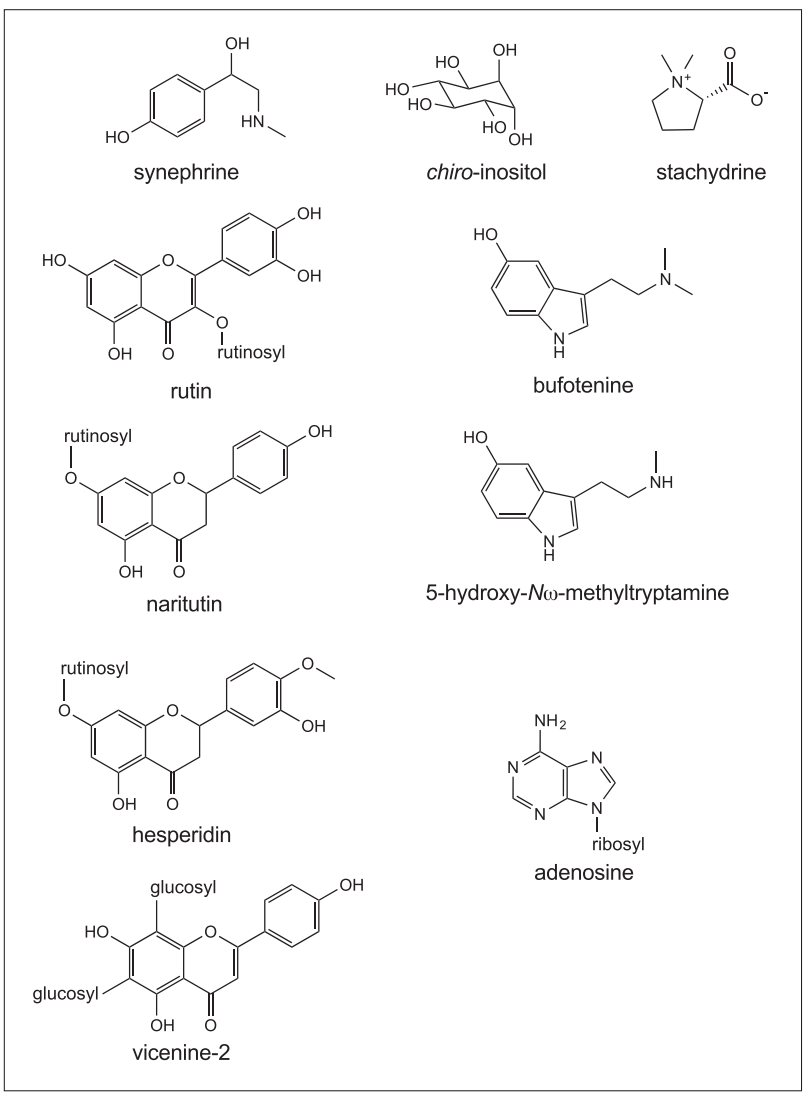

図 2 - シトラス属植物から同定されたナミアゲ八の産卵刺激物 質

10 種の化合物をすべて混ぜると, 生の葉と同等の産卵活性が観察 されるが，単独の溶液ではどれも産卵活性がない．

葉と同程度に産卵行動を誘発する ${ }^{(1)}$. 興味深いことに, 産卵刺激物質はどれも単独では全く産卵行動を誘発する ことができず，最低 2 種類以上の混合が必須である。こ の化合物を認識する仕組みが変化して食性が変わると棲 み分けが起こり，それをきっかけとして種分化が起きる のではないかと考えられる.

脊椎動物などほかの生物と同様に, 昆虫の味覚・嗅覚 には7回膜貫通型の受容体 (7TMP) が働いている。し かし, 昆虫の化学感覚受容体は塩基配列の保存性が極端 にそしく，既知の受容体遺伝子の配列情報を手がかりと して探索するのは困難であったため, 大部分は全ゲノム が解読された昆虫からコンピュー夕を使って探索されて いる．ゲノムが解読されていないナミアゲハから新規の 7TMPを探索するには, 独自の工夫が必要であった.

まず，未知の遺伝子を探索することを目的として，プ ラスミドベクターに組み込むまでの手順を最少化する工
夫を凝らして cDNAライブラリーを作成した ${ }^{(2)}$. 次に， 磁性ビーズを用いたプラスミド精製キットを使って，96 穴プレートで手作業でも大量に精製できる工夫をした。 こうして各種自動化装置などがない小規模な研究室であ りながら，キャピラリー式シーケンサーを使って1万ク ローン以上の塩基配列を短期間で決定した。配列が読め たらコンピュータの出番である. 塩基配列をアミノ酸配 列に変換し，膜貫通領域をもつものが見つかったら全長 配列を決定するという作業を繰り返した結果，1989番 目に解析した遺伝子のみがメ久成虫ふ節に特異的に発現 する7TMPであった（図1B）。

メス成虫のふ節で発現する7TMPが見つかったので, 産卵刺激物質の認識にかかわっているか確認する必要が ある．受容体が化合物を認識すると化学感覚ニューロン 内のカルシウム濃度が上昇するという反応が起きるの で，カルシウムに反応して蛍光を発する物質を使って, 蛍光を検出するのが一般的である。このような実験方法 をカルシウムイメージング法というが, 蛍光検出装置は 高価であるため, 安価で購入できる微弱発光計測装置を 改造してリアルタイムに発光量の変化を計測できる装置 を作製した。そして，受容体遺伝子と同時にイクオリン (aequorin: 発光クラゲから見つかった, カルシウム依 存的に発光するタンパク質）の遺伝子をバキュロウイル 久異所的発現系を用い，本来味覚に関する機能をもたな い培養昆虫細胞内で発現させた。これを化合物溶液で刺 激することで, 細胞の発光を観測できる. 培養細胞の数 と感染させるバキュロウイルスの数を適切に調整し，感 染後の培養期間を適度にすることで，再現性の高い結果 が得られることを確認した。この半手作りカルシウムイ メージング措置により，ナミアゲ八の7TMPは産卵刺 激物質の一つであるシネフリンに特異的に反応する化学 感覚受容体であることが確認できた（図3).シネフリ ンへの応答は，ミカンの葉から抽出した化合物すべてが 混合された溶液と同等であった（図3)。味覚細胞では ない培養細胞が, $7 \mathrm{TMP} の$ 異所的発現によって味覚機能 を獲得したのである。

また，7TMP遺伝子の部分配列（392塩基）から合成 した二重鎖 RNA（dsRNA）が存在すると，培養細胞内 での遺伝子発現を阻害し受容体機能を抑制することを確 認した。

遺伝子の働きを調べるには, その遺伝子のメッセン ジャーRNAの発現を阻害するため, dsRNAを生体に 


\section{今日の話題}

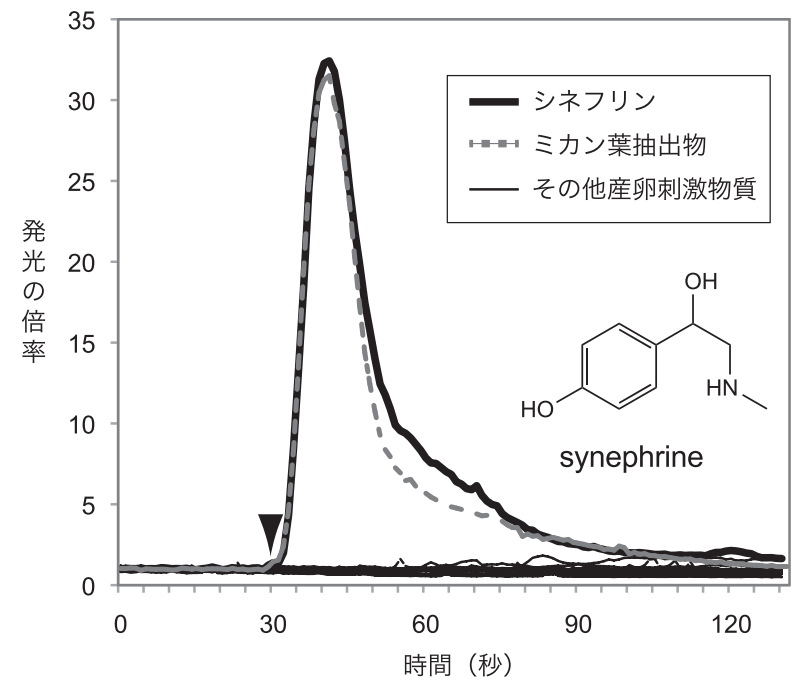

図3・カルシウムイメージング法によるナミアゲハ7TMPを発 現させた培養昆虫細胞の発光の比較

発光の倍率は, 刺激を行う前の状態を 1 として, 相対的な発光の 強さを表す。矢頭は，化合物溶液を入れたタイミングを示す。

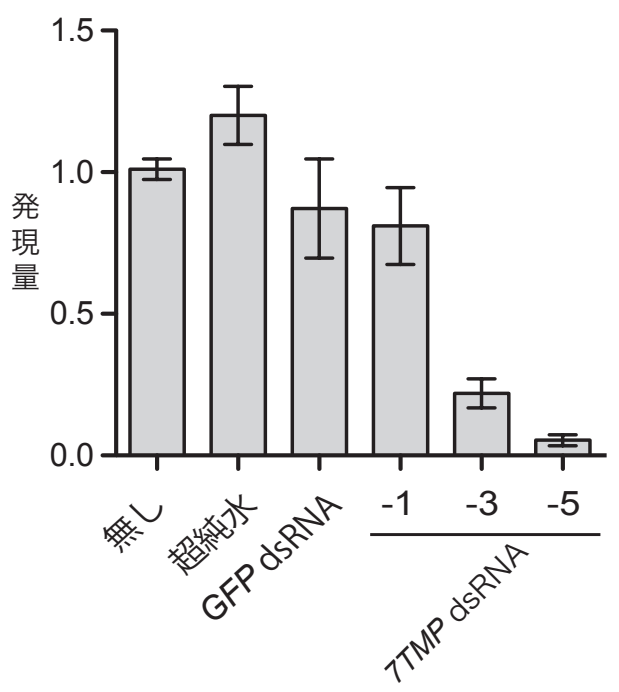

図 4 『定量的RT-PCRを用いた，二重鎖RNA注射によるナミ アゲハ7TMP遺伝子発現量への影響の確認

羽化直後の成虫からふ節をとり，発現量を調べた。 -1 : 羽化前日 に注射， -3 : 羽化 3 日前に注射， -5 : 羽化 5 日前に注射. 比較対 象区（注射なし, 超純水, GFP dsRNA）はすべて, 羽化5日前に 注射.

導入するRNA干渉（RNAi）がよく使われる．しかし鱗 翅目昆虫では, dsRNAの注射によって遺伝子の発現量 を抑えることはできるが，その効果が持続せず，この方 法による機能阻害は難しいとされてきた。しかし私たち

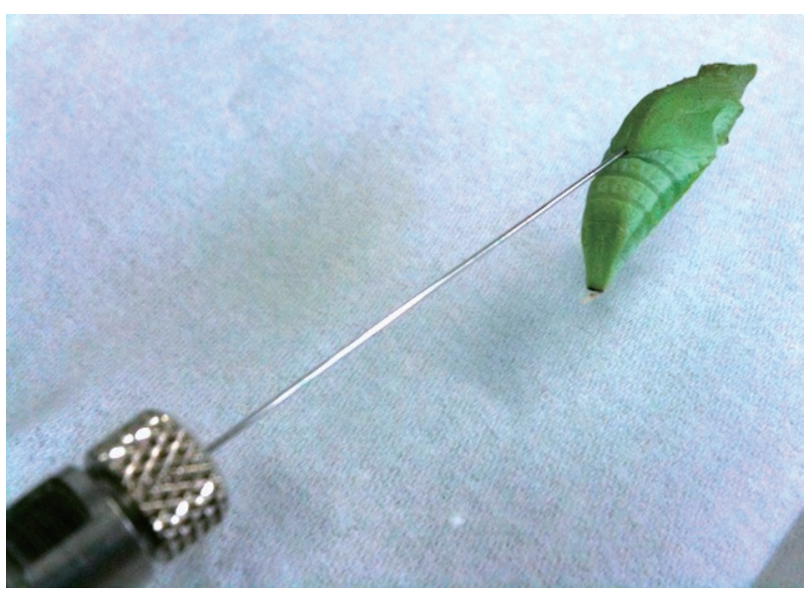

図 5 -蛹へのdsRNA 溶液の注射

メスの蛹に対し, 胸部と腹部の境界部分に, 斜め後方から細い注 射針を突き刺し， $1 \mu \mathrm{g} / \mu \mathrm{L}$ の dsRNA 溶液を $10 \mu \mathrm{L}$ 注入する.

は，ナミアゲハ7TMPの発現量がピークになる前に dsRNAを導入し，発現レベルの低い状態が維持される ようにすれば，阻害効果が得られるのではないかと考え た．そこで成虫だけでなく蛹からもふ節を取り出し，定 量的RT-PCR (quantitative RT-PCR) でナミアゲハ 7TMPの発現量を調べてみると, 羽化3日前から発現が 始まり，羽化前日の蛹で発現量がピークとなることがわ かった。そこで，羽化日を0日として $-1,-3,-5$, $-7,-9$ 日の蛹にdsRNAを注射で導入し, 羽化直後の 発現量を調べてみた結果, 蛹化後の早い時期にdsRNA を注射するほどこの遺伝子の発現を効果的に抑制できる ことがわかった（図4).しかし，蛹化後早い時期は体 が柔らかく，注射によるダメージが大きいためか，蛹の 死亡率がやや高まる傾向がある。十分な遺伝子発現抑制 効果が得られ, 蛹の死亡率は低い時期として, 羽化 5 日 前が最良と考え, 以後の RNAi実験では, 羽化5日前の 蛹にdsRNAを注射した（図5).

ナミアゲ八の7TMPが生体内でシネフリン受容体と して機能しているのか確かめるため, メス成虫の前脚を 使って電気生理実験を行った。化学感覚ニューロンがリ ガンドを認識すると, 活動電位が発生する。生物の組織 に電極を固定して，ニューロンを流れる微弱な電気の電 圧変化を測定するのが電気生理実験である。ナミアゲハ から切り取った前脚の付け根に電極を㨂入し，化合物の 溶液を満たした電極で感覚子の先端に触れることで, 化 学感覚ニューロンの反応を検出することができる．正常 なチョウの場合，60\%を超える感覚子がシネフリンに反 


\section{今日の話題}

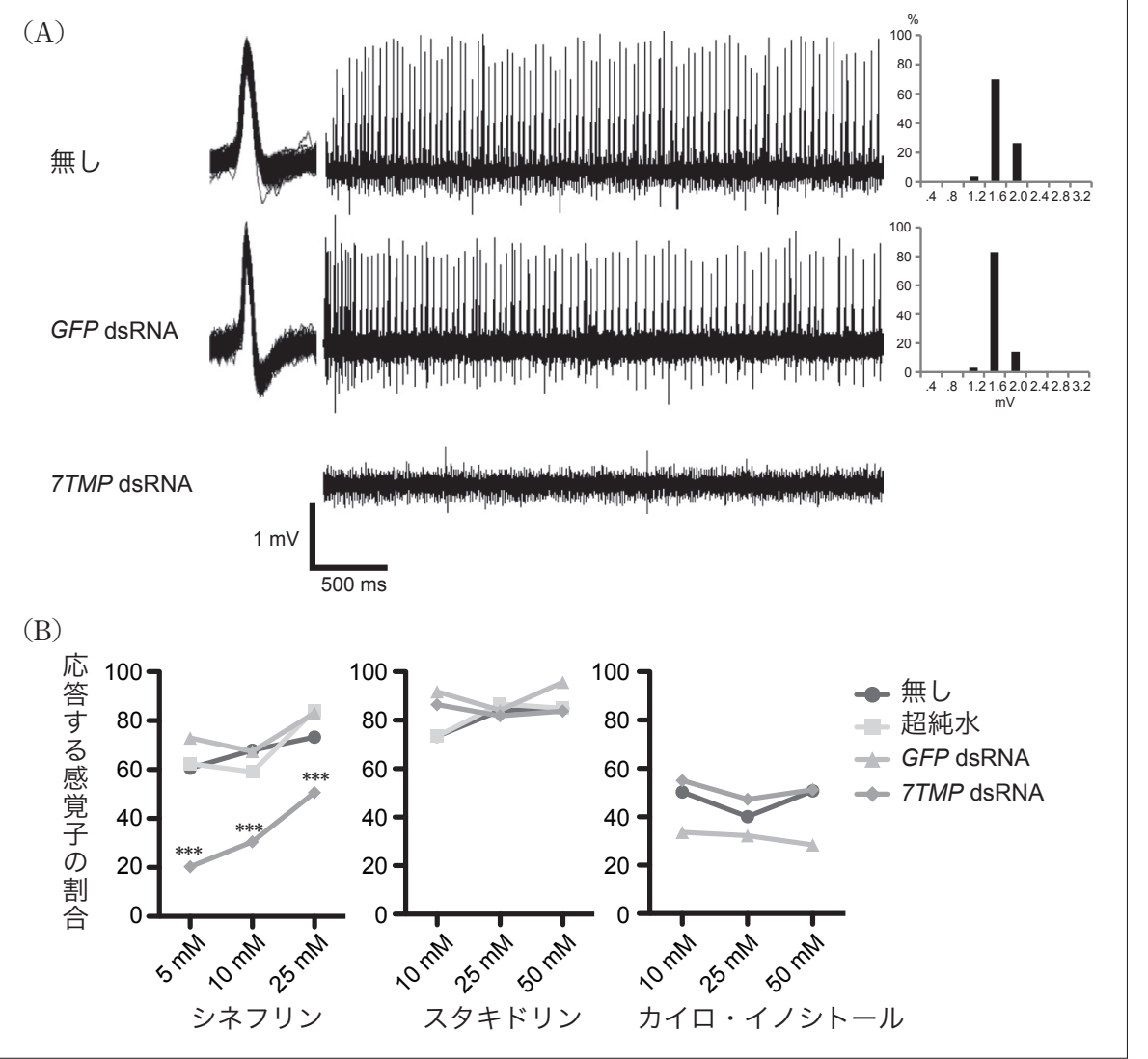

\section{図6 - 電気生理実験}

A : シネフリンによる刺激への感覚子 の応答. 7TMP dsRNAの注射によ り, 応答が消えている. GFP dsRNA の注射では，全く影響を受けていな い. B:RNAiチョウとノーマルの チョウの, 化合物に対する応答の比 較.シネフリンの刺激に応答する感 覚子の割合は, 7TMP dsRNAの注射 により有意に減少しているが $(p<$ 0.001), スタキドリンやカイロ・イノ シトールによる刺激では, 変化が見 られない。

応した。

これに対し，RNAi処理を施したナミアゲハ（RNAi チョウ）の前脚では，シネフリンによる刺激に対してだ け化学感覚ニューロンの応答が有為に減少し, スタキド リンやカイロ・イノシトールといった別の化合物での刺 激に対しては，応答は変化しなかった（図6)。また, ナミアゲハ7TMP と無関係である GFP遺伝子の dsRNA を注射した場合，シネフリンへの応答に変化は見られな かった。この結果により，ナミアゲハ7TMPが感覚子 ニューロンでシネフリンに特異的に応答する受容体とし て機能していることが確認できた.

最後に, RNAiチョウを用いて自由飛翔による産卵実 験を行った。アゲハチョウの仲間の産卵行動は飛ぶこと から始まる．自由に飛び回り，主に視覚を利用して半ば 手当たりしだいに植物へ着地し, 前脚で植物を吅くドラ ミングによって産卵するか否か判断する。 そこで，チョ

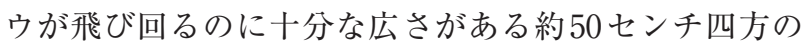
容器の中にナミアゲ八を放し，プラスチック製の人工葉 を見せて, メス成虫が自ら人工葉に接近・ドラミング

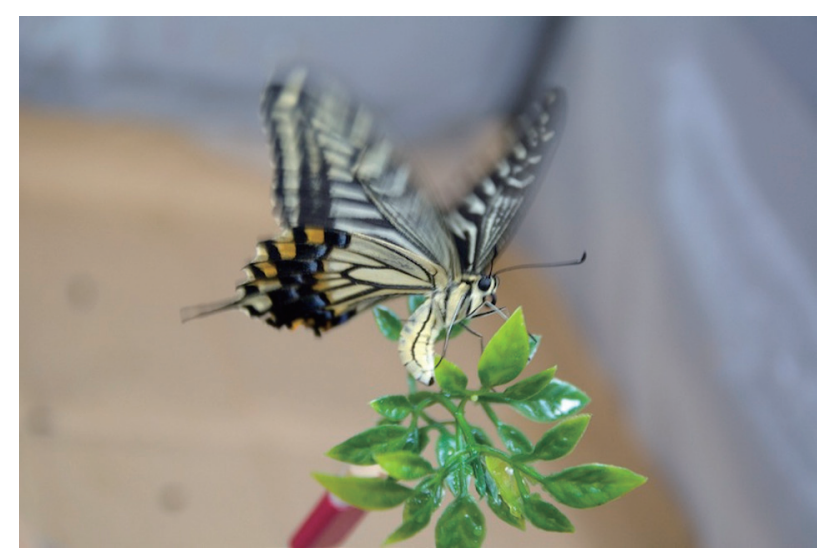

図7ロナミアゲハの産卵実験

ミカン葉抽出物（産卵刺激物質を含む）を塗布した人工葉に産卵 している様子.

し，産卵するか否かを観察するという気の長い実験を行 うのである（図7). RNAiを施していない通常のナミア ゲ八のメス成虫に，ミカンの葉から抽出した化合物や， 10 種類ある産卵刺激物質のうち水に溶けやすい 5 種類を 
表1 - 7TMP dsRNA の注射による産卵行動への影響（産卵率\%）

\begin{tabular}{lcccc}
\hline & \multicolumn{4}{c}{ 注射 } \\
\cline { 2 - 5 } 刺激物質 & なし & 超純水 & GFP dsRNA & 7TMP dsRNA \\
\hline 超純水 & 0 & 0 & 0 & 0 \\
シネフリン (A) & 0 & 0 & 0 & 0 \\
カイロ・イノシトール & 0 & 0 & 0 & 0 \\
混合液 $(\mathrm{A})+(\mathrm{B})$ & 72.1 & 77.8 & 62.5 & 21.1 \\
ミカン葉抽出物 & 100 & 100 & 100 & 100 \\
\hline
\end{tabular}

試験個体数：注射なし：43, 超純水：9, GFP dsRNA：16, 7TMP dsRNA：19. 混合液 (A) + （B）の有意差：注射なし $v s$. RNAiチョウ : $p<0.001$, 超純水 $v s$. RNAiチョウ : $p<0.001$, GFP dsRNA $v$ s. RNAiチョウ : $p<0.001$, two-way ANOVA (Fisher LSD)

混ぜた溶液を塗布した人工葉を触らせた場合，生の葉を 触らせた場合と同等の高い産卵活性を示す。水溶性の産 卵刺激物質のうち，シネフリンとカイロ・イノシトール の 2 種類だけを混ぜた場合には，生の葉と比較して約 $70 \%$ の産卵活性が見られる。しかし，どの産卵刺激物質 も，単独では全く産卵活性がない，そこで，RNAiに よってシネフリン受容体であるナミアゲハ7TMPの発 現を抑制したチョウは，シネフリンを認識できないのだ から，シネフリンとカイロ・イノシトールの混合溶液に 触らせても，カイロ・イノシトールのみでの産卵実験と 同じように卵を産まなくなるはずだと考えた。

実際に，容器内で自由に飛翔するRNAiチョウにシネ フリンとカイロ・イノシトールの混合液を付着させた人 工葉を提示したところ, 飛翔行動とドラミング行動は通 常のチョウと全く変わらないのに, 産卵活性が有意に低 下した（表1)。通常，卵を産む場合には，ドラミング の直後に迷うことなく腹部を曲げて卵を産みつけ，産ま ない場合はあっさりと飛び去ってしまう．水や単独の産 卵刺激物質溶液を塗布した人工葉など産卵刺激がない場 合，ドラミングの直後にさっと飛び去る．チョウはドラ ミングによって極短時間で卵を産むか否かを判断するの である。 それに対し，シネフリンとカイロ・イノシトー ルの混合溶液に触れたRNAiチョウでは, 普通のチョウ とは比べものにならないくらい長時間ドラミングを繰り 返し，さんざん悩んだあげく卵を産まずに飛び去るとい う独特な行動が観察された。おそらく，RNAiによる遺 伝子の発現阻害（遺伝子ノックダウン）では, 遺伝子自 体を破壊する遺伝子ノックアウトと違って発現を完全に なくすることはできないので, RNAiチョウもほんの少 しだけシネフリンの味を感じることができているのでは ないだろうか. しかし産卵活性を引き起こす閾值には達
しない程度の刺激であるため，悩んだ末に産まないとい う判断をしているのではないかと思われる。このような “迷い”は，RNAiという実験手法だからこそ観察でき た行動であろう。RNAiチョウもミカン葉抽出物や生葉 には正常に産卵し, 水や単独化合物の水溶液ではすぐに 飛び去ることから，RNAiによる遺伝子発現阻害の影響 は，シネフリンの認識のみにみられる現象である。この 結果により，ナミアゲハ7TMPが産卵刺激物質受容体 として産卵行動に関与していることが確認できた。

以上で見てきたとおり，in silico（コンピュータ上の 解析）・in vitro（生体外での実験）・in vivo（生体を 使っての実験）の総合的な研究により，私たちが発見し た受容体遺伝子は，産卵刺激物質の一つであるシネフリ ンを特異的に認識し, 産卵行動の誘発に関与すること で，ナミアゲハの食草認識において重要な役割を担って いることがわかった ${ }^{(3)}$. 研究例の多いショウジョウバエ ですら，機能が解明されている味覚受容体はまだ少ない なか，産卵という本能行動に関与する味営受容体をナミ アゲ八から解明できた意味は大きいと考えている.

アゲ八チョウ科昆虫の進化の歴史のなかで, 産卵刺激 物質受容体遺伝子に何らかの変化が起こり認識する化合 物が変わる，または発現するニューロンが変わることで 同じ物質に別の意味をもたせるといった変化が食草の認 識に影響を与えたのではないだろうか。私たちは，チョ ウの仲間が食草を転換することを出発点として棲み分け が起こり，それをきっかけとして種分化につながったの ではないか，という仮説の証明を目指している，今後は 格段に安くなってきた次世代型シーケンサーの能力を最 大限に活用し，複数種のアゲ八チョウの仲間から産卵刺 激物質の認識にかかわる遺伝子を複数見つけ，その変化 を比較することで, 植食性昆虫の進化・多様化の仕組み 
について理解を深め，アゲハチョウの仲間が種分化の出 発点に立ったときにゲノム上で何が起きていたのかを知 る手がかりを見つけたいと考えている。

謝辞：本研究の遂行にあたり，谷村禎一先生，石元広志博士（九州大 学), Frederic Marion-Poll先生, Delphine Calas博士（INRA）に多大な ご協力をいただいたことに感謝いたします。

1) T. Ohsugi, R. Nishida \& H. Fukami : Applied Entomology and Zoology, 26, 29 (1991).

2) K. Ozaki, A. Utoguchi, A. Yamada \& H. Yoshikawa: Insect Biochem. Mol. Biol., 38, 969 (2008).

3) K. Ozaki, M. Ryuda, A. Yamada, A. Utoguchi, H. Ishimoto, D. Calas, F. Marion-Poll, T. Tanimura \& H. Yoshikawa:Nat. Commun., 2, 542 (2011), doi:10.1038/ncomms1548.

（尾崎克久, 龍田勝輔, 吉川 寛, JT生命誌研究館）

\section{プロフィル}

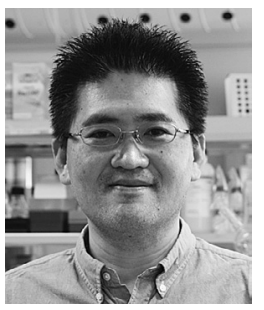

尾崎 克久 (Katsuhisa OZAKI)

$<$ 略歴 $>2000$ 年岩手連合大学院（弘前大 学) 農学研究科博士課程修了/2000 2001 年農林水産省生物系特定産業技術推 進機構ポスドク／2001 ～2004年JT生命誌 研究館奨励研究員（ポスドク）/2004年〜 現在, JT生命誌研究館研究員 $<$ 研究テー マと抱負 >分子の情報を手がかりとして, 生命現象を司るメカニズムを解明し，生命 現象を深く理解していきたいと考えてい る. 莫大に蓄積されている生態学的知見 と, 爆発的に増え続ける分子の情報を融合 させる研究に取り組みたい. なかでも化学 感覚は重要な役割をもつので, 味覚・嗅覚 の仕組みを中心に解明していきたいく趣 味〉子どもたちと遊ぶこと，景色の良いと ころへ出かけて写真撮影

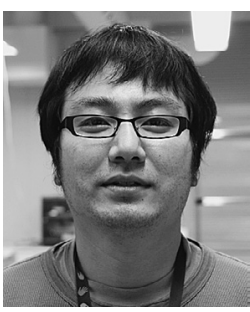

龍田＼cjkstart勝輔（Masasuke RYUDA）

<略歴 $>2008$ 年鹿児島大学大学院連合農 学研究科修了 $/ 2008 \sim 2009$ 年佐賀大学農 学部特定研究員 $/ 2009$ 年 現在, JT生命 誌研究館奨励研究員＜研究テーマと抱負 $>$ 電気生理学的手法によるアゲハチョウ科昆 虫の産卵刺激物質受容メカニズムの解明／ 〈趣味>水棲生物の飼育（アクアリウム）, 釣り

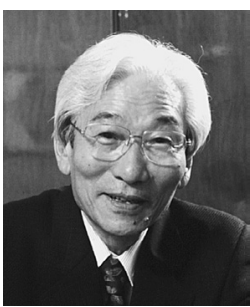

吉川寛 (Hiroshi YOSHIKAWA)

$<$ 略歴>1975年東京大学理学部化学科 卒 / 1961年東京大学理学系大学院博士課 程修了/同年米国イリノイ大, プリンスト ン大でポスドク／1964～1969年米国カリ フォルニア大 (バークレイ校) 助教授, 准 教授/1969 1985年金沢大学癌研究所教 授／1986～1993年大阪大学医学部教授, 名誉教授 / 1993 2001年奈良先端科学技 術大学院大学教授, 名誉教授 /2001 2006 年 JT生命誌研究館顧問 < 研究テーマ と抱負 >遺伝学，分子生物学，ゲノム科学 の歴史，昆虫の本能などに興味をもち，読 書, 執筆活動を行っている<趣味 $>$ 昆虫採 集を卒業して, 専らデジタルカメラで蝶の 生態を収集している 